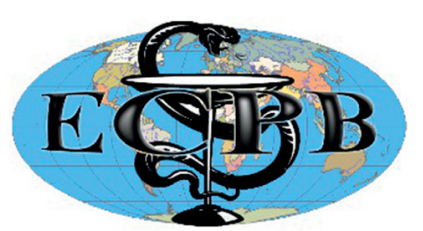

ЕКСПЕРИМЕНТАЛЬНА ТА КЛІНІЧНА ФІЗІОЛОГІЯ І БІОХІМІЯ» "EXPERIMENTAL AND CLINICAL PHYSIOLOGY AND BIOCHEMISTRY" Науково-практичний журнал/Scientific-practical journal

Наукові статті / Research Articles

ECPB 2021, 1/2(92): 49-58. https://doi.org/

\title{
Metabolic accompaniment of individual immune responses to chronic stress in female rats
}

\author{
O.I. MEL'NYK' , I.L. POPOVYCH ${ }^{2,3}$
}

\author{
${ }^{1}$ Danylo Halyts'kyı̌ National Medical University, L'viv, Ukraine \\ E-mail:melnyk_oksana@meduniv.lviv.ua
}

${ }^{2} \mathrm{OO}$ Bohomolets' Institute of Physiology, Kyiv, Ukraine

E-mail:i.popovych@biph.kiev.ua

${ }^{3}$ Ukrainian Scientific Research Institute for Medicine of Transport, Odesa, Ukraine

\begin{abstract}
We have previously shown that the immune responses of female rats to chronic immobilization-aversion stress are ambiguous and can be grouped into at least three clusters. The aim of this study is to identify the peculiarities of metabolism in different variants of the immune response to chronic stress in the same animals. Material and methods. The experiment was performed on 60 healthy Wistar female rats weighing 220-300 g. 10 animals remained intact, and the other rats 6 days subjected to moderate stress by daily 30-minute immobilization. The day after the completion of the stressing course we determined the plasma levels of the electrolytes (calcium, magnesium, phosphates, potassium); nitrogenous metabolites (creatinine, urea, uric acid, bilirubin); middle mass molecules, amylase, glucose, cholesterol as well as lipids peroxidation parameters (diene conjugates, malonic dialdehyde, catalase plasma and superoxide dismutase erythrocytes). The level of sodium determined in erythrocytes. Most of the listed parameters of metabolism were also determined in daily urine. Glomerular filtration, canalicular reabsorption and lithogenicity of urine were calculated. Results. Based on the discriminant analysis by the forward stepwise method, 22 parameters are included in the model. Members of first cluster with minimal stress induced immune dysfunction are characterized by higher than normal levels of glomerulary filtration, diurese, phosphates excretion, calcium urine and malonic dialdehyde plasma, and normal levels of body mass, potassium urine and magnesium plasma but maximum among stressed animals, as well as lower than normal activity of superoxide dismutase and normal but minimal for sampling levels of canalicular reabsorbtion, uric acid plasma and sodium erythrocytes. The members of the second cluster with maximal immune dysfunction are characterized by decreased/increased or minimum/maximum levels of the listed parameters of metabolism. The members of the third cluster are characterized by higher than normal plasma levels of phosphate, creatinine, urea and amylase, as well as lower than normal urine levels of uric acid, middle mass molecules, diene conjugates and lythogenicity urine as well as normal but maximal for sampling levels of katalase urine and diene conjugates plasma. Overall classification accuracy is $92 \%$. Conclusion. The previously identified three variants of immune responses to chronic stress are accompanied by characteristic constellations of metabolic parameters.
\end{abstract}


Key words: chronic stress, electrolytes, nitrogenous metabolites, lipids peroxidation, female rats, discriminant analysis.

\title{
Метаболічний супровід індивідуальних імунних реакцій на хронічний стрес у самиць щурів
}

\author{
O.I. МЕЛЬНИК \\ ${ }^{1}$ Львівський національний медичний університет ілені Данила Галицького, \\ Львів, Украӥна \\ ${ }^{2}$ Інститут фбізіологї іл. О.О. Богомольия, Київ, Украӥна
}

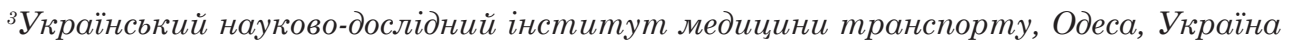

Резюме. Раніше ми показали, що імунна реакція самиць щурів на хронічний іммобілізаційно-аверсійний стрес неоднозначна і може бути згрупована принаймні в три кластери. Метою цього дослідження $є$ виявлення особливостей метаболізму за різних варіантів імунної відповіді на хронічний стрес у тих самих тварин. Матеріал і методи. Експеримент проводили на 60 здорових самицях щурів лінії Вістар масою 220-300 г. 10 тварин залишалися інтактними, а інші щури впродовж 6 днів піддавались помірному стресу шляхом 30-хвилинної іммобілізації. На наступний день після завершення курсу стресування ми визначили рівні електролітів у плазмі (кальцій, магній, фросфати, калій); азотистих метаболітів (креатинін, сечовина, сечова кислота, білірубін); молекул середньої маси, амілази, глюкози, холестерину, а також параметри перекисного окислення ліпідів (дієнові кон'югати, малоновий діальдегід, каталаза плазма та супероксиддисмутаза еритроцитів). Рівень натрію визначали в еритроцитах. Більшість перелічених параметрів метаболізму визначали також у добовій сечі. За формулами розраховували клубочкову фрільтрацію, канальцеву реабсорбцію та літогенність сечі. Результати. На основі дискримінантного аналізу у модель включено 22 параметри. Члени першого кластера 3 мінімальною спричиненою стресом імунодисдрункцією характеризуються вищими за норму рівнями клубочкової фрільтрації, діурезу, екскреції фросфратів і кальцію із сечею та малонового диальдегіду плазми, а також нормальними рівнями маси тіла, калію сечі та магнію плазми, але максимальними серед стресованих тварин, а також нижчою за нормальну активністю супероксиддисмутази і нормальними, але мінімальними для вибірки рівнями канальцевої реабсорбції, сечової кислоти плазми та натрію еритроцитів. Члени другого кластера з максимальною імунною дисфункцією характеризуються зниженими/підвищеними або мінімальними/максимальними рівнями перелічених параметрів метаболізму. Члени третього кластера характеризуються вищими за норму рівнями в плазмі фросфату, креатиніну, сечовини та амілази, а також нижчими за норму рівнями сечової кислоти, молекул середньої маси, дієнових кон'югатів та літогенності сечі, а також нормальними, але максимальними для вибірки рівнями каталази сечі та дієнових кон'югатів плазми. Загальна точність класифікації становить $92 \%$. Висновок. Виявлені раніше три варіанти імунної відповіді на хронічний стрес супроводжуються характерними сузір'ями метаболічних параметрів.

Ключові слова: хронічний стрес, електроліти, азотисті метаболіти, перекисне окислення ліпідів, самки щурів, дискримінантний аналіз.

Introduction. We have previously shown that the immune responses of female rats to chronic immobilization-aversion stress are ambiguous and can be grouped into at least three clusters. Characteristic features of the immune image of members of the pessimal cluster №2 (24\%) are a decrease in spleen mass in combination with an increase in the proportion in the splenocytogram 
of lymphoblasts and neutrophils, a decrease in the proportion in the thymocytogram of endothelial cells and T-lymphocytes combined with an increase in its entropy, a decrease in the content of leukocytes in general and the proportion in the leukocytogram of basophils and eosinophils in combination with an increase in the proportion in the immunocytogram of natural killers, as well as the normal content in the thymocytogram of lymphoblasts. In contrast, members of the cluster №3 (28\%) under similar conditions showed a significant decrease in lymphoblasts in the thymocytogram and splenocytogram, while the content of neutrophils and leukocytes in the spleen did not differ from those in intact control, and the mass of the spleen, the content of endothelial cells in the thymocytogram and basophils in the blood were even higher than normal. A characteristic feature of the members of the largest cluster №1 (48\%) was a decrease in the content of neutrophils in the splenocytogram, while the other listed parameters of immunity did not differ significantly from intact control or deviations were minimal.

Among neuroendocrine parameters, the members of the cluster №2 differed from others by a moderately reduced adrenal mass with normal thickness of the fascicular zone of their cortex, as well as parathyroid and calcitonin activities, while sympathetic tone and heart rate increased moderately. Characteristic features of rats of cluster №3 were normal adrenal mass in combination with significantly thickened fascicular zone and tachycardia and reduced activity of parathyrin and calcitonin. In contrast, members of the cluster №1 were characterized by moderately increased adrenal mass and thickened fascicular zone, normal levels of sympathetic tone, heart rate, and calcitonin activity in combination with moderately reduced parathyroid activity [1-4].

Preliminary analysis revealed numerous links between neuroendocrine-immune and metabolic parameters [5], consistent with the concept of functional-metabolic continuum [6].

The aim of this study is to identify the peculiarities of metabolism in different variants of the immune response to chronic stress in the same animals.

Material and Methods. The experiment was performed on 60 healthy Wistar female rats weighing 220-300 g. 10 animals remained intact, and the other rats 6 days subjected to moderate stress by daily 30-minute immobilization [7]. The day after the completion of the stressing course animals were placed in individual chambers with perforated bottom for collecting daily urine. The experiment was completed by decapitation of rats in order to collect as much blood as possible.

We determined the plasma levels of the electrolytes: calcium (by reaction with arsenase III), magnesium (by reaction with colgamite), phosphates (phosphate-molybdate method), potassium (by flamming photometry); nitrogenous metabolites: creatinine (by Jaffe's color reaction by Popper's method), urea (urease method by reaction with phenolhypochlorite), uric acid (uricase method), bilirubin (by diazoreaction using the Jedrashik-Kleghorn-Grof method); middle mass molecules (by spectrophotometric method); amylase (Karavay's amyloclastic method with starch substrate), glucose (glucose-oxidase method), cholesterol (by a direct method after the classic reaction by Zlatkis-Zack) [8] as well as lipid peroxidation products: diene conjugates (spectrophotometry of the heptane phase of the lipids extract [9]) and malonic dialdehyde (in the test with thiobarbituric acid [10]), antioxidant enzymes: superoxide dismutase erythrocytes (according to the degree of inhibition of reduction of nitroblue tetrazolium in the presence of $\mathrm{N}$-methylphenazonium metasulphate and $\mathrm{NADH}[11,12]$ ) and catalase plasma (at the rate of decomposition of hydrogen peroxide [13]).

The level of sodium determined in erythrocytes (by flamming photometry).

Most of the listed parameters of metabolism were also determined in daily urine. By the size of the diuresis and the level of creatinine in plasma and urine, glomerular filtration and canalicular reabsorption were calculated. In addition, the lithogenicity of urine was calculated by the formula [14]: 
Lithogenicity $=[(\mathrm{Ca} \cdot \mathrm{UA}) /(\mathrm{Mg} \cdot \mathrm{Cr})]^{0,25}$.

The analyzes were carried out according to the instructions described in the manual [8]. The analyzers "Pointe-180" ("Scientific", USA) and "Reflotron" (Boehringer Mannheim, BRD) were used with appropriate sets and a flamming spectrophotometer "CФ-47".

Digital material is statistically processed on a computer using the software package "Statistica 20 ".

Results and discussion. Based on the discriminant analysis by the forward stepwise method [15], 22 parameters are included in the model (Table 1). The remaining parameters were out of the model (Table 2 ).

Table 1.

Discriminant Function Analysis Summary. Variables currently in the model

Step 22, $\mathrm{N}$ of variables currently in the model: 22; Grouping: 3 groups Wilks' Lambda: 0,0789; approx. $\mathrm{F}_{(45)}=3,02 ; \mathrm{p}<10^{-4}$

\begin{tabular}{|l|c|c|c|c|c|}
\hline \multicolumn{1}{|c|}{$\begin{array}{c}\text { Variables currently in the } \\
\text { model }\end{array}$} & \multicolumn{5}{|c|}{ Parameters of Wilks' Statistics } \\
\cline { 2 - 6 } & $\begin{array}{c}\text { Wilks' } \\
\boldsymbol{\Lambda}\end{array}$ & $\begin{array}{c}\text { Partial } \\
\boldsymbol{\Lambda}\end{array}$ & $\begin{array}{c}\text { F-remove } \\
\mathbf{( 2 , 2 6 )}\end{array}$ & $\begin{array}{c}\text { p- } \\
\text { level }\end{array}$ & Tolerancy \\
\hline Phosphate Plasma & 0,084 & 0,945 & 0,76 & 0,477 & 0,365 \\
\hline Body Mass & 0,131 & 0,601 & 8,63 & 0,001 & 0,193 \\
\hline Uric Acid Excretion & 0,082 & 0,968 & 0,43 & 0,653 & 0,025 \\
\hline Diene conjugates Urine & 0,090 & 0,880 & 1,78 & 0,188 & 0,438 \\
\hline Uric Acid Plasma & 0,099 & 0,795 & 3,36 & 0,051 & 0,224 \\
\hline Urea Plasma & 0,115 & 0,689 & 5,87 & 0,008 & 0,045 \\
\hline Malonic Dialdehyde Plasma & 0,111 & 0,711 & 5,28 & 0,012 & 0,180 \\
\hline Glomerulary Filtration & 0,097 & 0,816 & 2,94 & 0,071 & 0,126 \\
\hline Middle Mass Molecules Urine & 0,106 & 0,745 & 4,45 & 0,022 & 0,231 \\
\hline Sodium Erythrocytes & 0,092 & 0,860 & 2,11 & 0,142 & 0,217 \\
\hline Phosphates Excretion & 0,132 & 0,599 & 8,72 & 0,001 & 0,039 \\
\hline Uric Acid Urine & 0,082 & 0,962 & 0,52 & 0,603 & 0,026 \\
\hline Creatinine Plasma & 0,114 & 0,695 & 5,70 & 0,009 & 0,029 \\
\hline Canalicular Reabsorbtion & 0,092 & 0,856 & 2,19 & 0,132 & 0,070 \\
\hline Katalase Urine & 0,119 & 0,666 & 6,53 & 0,005 & 0,219 \\
\hline Diene conjugates Plasma & 0,081 & 0,969 & 0,41 & 0,666 & 0,252 \\
\hline Magnesium Plasma & 0,090 & 0,880 & 1,77 & 0,191 & 0,256 \\
\hline Amylase Plasma & 0,086 & 0,916 & 1,20 & 0,318 & 0,419 \\
\hline Diurese & 0,084 & 0,936 & 0,89 & 0,423 & 0,026 \\
\hline Calcium Urine & 0,101 & 0,783 & 3,61 & 0,042 & 0,224 \\
\hline Potassium Urine & 0,090 & 0,873 & 1,89 & 0,171 & 0,243 \\
\hline Superoxide Dismutase Erythr & 0,087 & 0,911 & 1,26 & 0,299 & 0,402 \\
\hline
\end{tabular}

Table 2 .

Discriminant Function Analysis Summary. Variables currently not in the model

\begin{tabular}{|l|c|c|c|c|c|}
\hline \multirow{2}{*}{$\begin{array}{c}\text { Variables currently not in } \\
\text { the model } \\
\text { (df for all F-tests: 2,25) }\end{array}$} & \begin{tabular}{c} 
Pilks' \\
\cline { 2 - 6 }
\end{tabular} & $\begin{array}{c}\text { Partial } \\
\Lambda\end{array}$ & $\begin{array}{c}\text { F to } \\
\text { enter }\end{array}$ & $\begin{array}{c}\text { p- } \\
\text { level }\end{array}$ & Tolerancy \\
\cline { 2 - 6 } Lythogenicity Urine & 0,078 & 0,991 & 0,11 & 0,895 & 0,161 \\
\hline Cholesterol Plasma & 0,077 & 0,975 & 0,33 & 0,725 & 0,377 \\
\hline Creatinine Excretion & 0,078 & 0,994 & 0,08 & 0,923 & 0,033 \\
\hline Creatinine Urine & 0,074 & 0,934 & 0,89 & 0,424 & 0,041 \\
\hline Potassium Excretion & 0,077 & 0,975 & 0,32 & 0,726 & 0,037 \\
\hline Magnesium Excretion & 0,078 & 0,983 & 0,22 & 0,804 & 0,188 \\
\hline
\end{tabular}




\begin{tabular}{|l|c|c|c|c|c|}
\hline \multirow{2}{*}{$\begin{array}{c}\text { Variables currently not in } \\
\text { the model } \\
\text { dff for all F-tests: 2,25) }\end{array}$} & \begin{tabular}{c} 
Wilks' \\
\cline { 2 - 6 }
\end{tabular} & $\begin{array}{c}\text { Partial } \\
\Lambda\end{array}$ & $\begin{array}{c}\text { F to } \\
\text { enter }\end{array}$ & $\begin{array}{c}\text { p- } \\
\text { level }\end{array}$ & Tolerancy \\
\hline Calcium Excretion & 0,077 & 0,970 & 0,39 & 0,683 & 0,074 \\
\hline Urea Excretion & 0,077 & 0,973 & 0,35 & 0,710 & 0,146 \\
\hline Urea Urine & 0,076 & 0,968 & 0,41 & 0,670 & 0,346 \\
\hline Magnesium Urine & 0,079 & 0,998 & 0,03 & 0,975 & 0,281 \\
\hline Phosphate Urine & 0,078 & 0,983 & 0,21 & 0,810 & 0,187 \\
\hline Potassium Erythrocytes & 0,076 & 0,959 & 0,53 & 0,594 & 0,520 \\
\hline Bilirubine Plasma & 0,076 & 0,963 & 0,48 & 0,625 & 0,396 \\
\hline Amylase Urine & 0,077 & 0,980 & 0,26 & 0,773 & 0,345 \\
\hline $\begin{array}{l}\text { Middle Mass Molecules } \\
\text { Plasma }\end{array}$ & 0,078 & 0,985 & 0,19 & 0,825 & 0,415 \\
\hline Katalase Plasma & 0,079 & 0,995 & 0,06 & 0,942 & 0,125 \\
\hline Malonic Dialdehyde Urine & 0,076 & 0,961 & 0,51 & 0,606 & 0,263 \\
\hline Glucose Plasma & 0,075 & 0,947 & 0,70 & 0,505 & 0,579 \\
\hline Potassium Plasma & 0,078 & 0,986 & 0,17 & 0,843 & 0,509 \\
\hline Calcium Plasma & 0,074 & 0,937 & 0,84 & 0,443 & 0,456 \\
\hline
\end{tabular}

The selection of discriminant variables is very clear (Table 3).

Table 3 .

Summary of Stepwise Analysis

\begin{tabular}{|l|c|c|c|c|c|}
\hline \multicolumn{1}{|c|}{$\begin{array}{c}\text { Variables } \\
\text { currently in the model }\end{array}$} & $\begin{array}{c}\text { F to } \\
\text { enter }\end{array}$ & $\begin{array}{c}\text { p- } \\
\text { level }\end{array}$ & $\boldsymbol{\Lambda}$ & F-value & $\begin{array}{c}\mathbf{p}- \\
\text { level }\end{array}$ \\
\hline Phosphate Plasma & 2,90 & 0,065 & 0,890 & 2,9 & 0,065 \\
\hline Body Mass & 2,74 & 0,075 & 0,796 & 2,8 & 0,031 \\
\hline Uric Acid Excretion & 3,98 & 0,026 & 0,676 & 3,2 & 0,006 \\
\hline Diene conjugates Urine & 2,66 & 0,081 & 0,603 & 3,2 & 0,003 \\
\hline Uric Acid Plasma & 2,29 & 0,113 & 0,545 & 3,0 & 0,002 \\
\hline Urea Plasma & 2,17 & 0,127 & 0,494 & 3,0 & 0,002 \\
\hline Malonic Dialdehyde Plasma & 1,66 & 0,202 & 0,457 & 2,8 & 0,002 \\
\hline Glomerulary Filtration & 2,77 & 0,075 & 0,401 & 2,9 & 0,001 \\
\hline Middle Mass Molecules Urine & 1,87 & 0,167 & 0,366 & 2,8 & 0,001 \\
\hline Sodium Erythrocytes & 3,30 & 0,048 & 0,312 & 3,0 & $10^{-3}$ \\
\hline Phosphates Excretion & 2,68 & 0,082 & 0,272 & 3,1 & $10^{-3}$ \\
\hline Uric Acid Urine & 3,28 & 0,049 & 0,230 & 3,2 & $10^{-4}$ \\
\hline Creatinine Plasma & 3,02 & 0,062 & 0,197 & 3,4 & $10^{-4}$ \\
\hline Canalicular Reabsorbtion & 2,05 & 0,144 & 0,175 & 3,4 & $10^{-4}$ \\
\hline Katalase Urine & 1,74 & 0,192 & 0,159 & 3,3 & $10^{-4}$ \\
\hline Diene conjugates Plasma & 2,00 & 0,153 & 0,141 & 3,3 & $10^{-4}$ \\
\hline Magnesium Plasma & 1,77 & 0,187 & 0,127 & 3,3 & $10^{-4}$ \\
\hline Amylase Plasma & 1,66 & 0,207 & 0,114 & 3,3 & $10^{-4}$ \\
\hline Diurese & 1,26 & 0,298 & 0,105 & 3,2 & $10^{-4}$ \\
\hline Calcium Urine & 1,43 & 0,256 & 0,095 & 3,1 & $10^{-4}$ \\
\hline Potassium Urine & 1,34 & 0,279 & 0,087 & 3,1 & $10^{-4}$ \\
\hline Superoxide Dismutase Erythr & 1,26 & 0,299 & 0,079 & 3,0 & $10^{-4}$ \\
\hline
\end{tabular}

The dividing information contained in 22 variables is condensed in two canonical discriminant roots (Table 4). The major root contains 70,4\% of discriminative opportunities, and the minor $29,6 \%$.

Next, the 22-dimensional space of discriminant variables transforms into 2 -dimensional space of canonical roots. The discriminating ability of the root 
characterizes the canonical correlation coefficient as the degree of dependence between clusters and a discriminant function. It is for Root 10,891 (Wilks' $\left.\Lambda=0,079 ; \chi^{2}{ }_{(44)}=93 ; p<10^{-4}\right)$, for Root 20,786 (Wilks' $\Lambda=0,382 ; \chi^{2}{ }_{(21)}=35 ; p=0,027$ ).

Table 4 shows standardized (normalized) and non-standardized (raw) coefficients for discriminant variables.

Table 4 .

Standardized and Raw Coefficients for Canonical Variables

\begin{tabular}{|l|c|c|c|c|}
\hline \multicolumn{1}{|c|}{ Coefficients } & \multicolumn{2}{c|}{ Standardized } & \multicolumn{2}{c|}{ Raw } \\
\hline Variables & Root 1 & Root 2 & Root 1 & Root 2 \\
\hline Phosphate Plasma & 0,239 & $-0,414$ & 0,4747 & $-0,8212$ \\
\hline Body Mass & 1,069 & $-1,368$ & 0,0496 & $-0,0635$ \\
\hline Uric Acid Excretion & 0,795 & 1,147 & 0,3077 & 0,4439 \\
\hline Diene conjugates Urine & 0,228 & 0,616 & 0,5420 & 1,4663 \\
\hline Uric Acid Plasma & $-1,071$ & 0,106 & $-0,0023$ & 0,0002 \\
\hline Urea Plasma & $-2,679$ & $-1,371$ & $-0,8350$ & $-0,4273$ \\
\hline Malonic Dialdehyde Plasma & 1,410 & 0,223 & 0,0492 & 0,0078 \\
\hline Glomerulary Filtration & 0,564 & $-1,401$ & 0,0062 & $-0,0154$ \\
\hline Middle Mass Molecules Urine & $-0,680$ & 1,093 & $-0,0169$ & 0,0272 \\
\hline Sodium Erythrocytes & 0,416 & $-0,905$ & 0,0843 & $-0,1834$ \\
\hline Phosphates Excretion & 3,565 & 0,571 & 0,7115 & 0,1139 \\
\hline Uric Acid Urine & 0,514 & $-1,437$ & 0,2680 & $-0,7489$ \\
\hline Creatinine Plasma & 3,506 & $-0,987$ & 0,1000 & $-0,0281$ \\
\hline Canalicular Reabsorbtion & 1,502 & $-0,659$ & 2,121 & $-0,9309$ \\
\hline Katalase Urine & $-1,381$ & $-0,163$ & $-0,0310$ & $-0,0037$ \\
\hline Diene conjugates Plasma & $-0,278$ & $-0,314$ & $-0,6295$ & $-0,7111$ \\
\hline Magnesium Plasma & $-0,281$ & $-0,810$ & $-0,5424$ & $-1,5632$ \\
\hline Amylase Plasma & $-0,189$ & $-0,530$ & $-0,0057$ & $-0,0160$ \\
\hline Diurese & $-1,513$ & $-1,044$ & $-2,0878$ & $-1,4415$ \\
\hline Calcium Urine & 1,086 & $-0,229$ & 1,0816 & $-0,2276$ \\
\hline Potassium Urine & 0,812 & 0,017 & 0,0177 & 0,0004 \\
\hline Superoxide Dismutase Erythr & $-0,458$ & 0,295 & $-0,0451$ & 0,0291 \\
\hline & \multicolumn{2}{|c|}{ Constants } & $-228,9$ & 119,5 \\
\hline & Eigenvalues & 3,841 & 1,617 \\
\hline & Cum. Propoptio & 0,704 & 1,000 \\
\hline
\end{tabular}

The calculation of the discriminant root values for each animal as the sum of the products of raw coefficients to the individual values of discriminant variables together with the constant enables the visualization of each rat in the information space of the roots. 


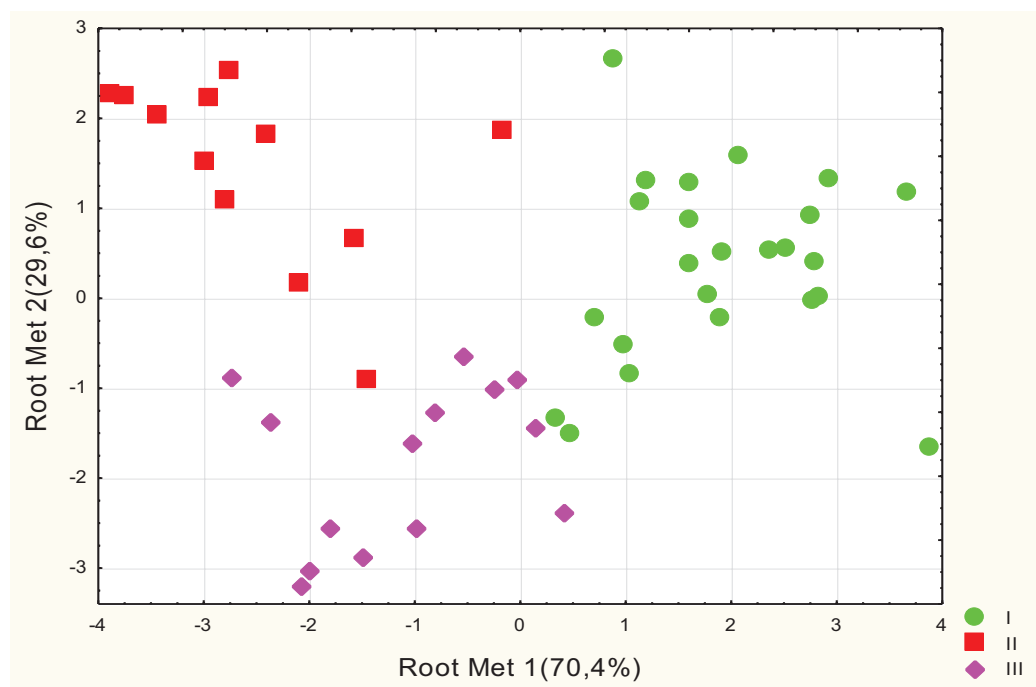

Fig. 1. Individual values of the first and second roots of the metabolic parameters in female rats of various immune clusters

On the whole, in the information space of the two discriminating roots, all clusters are clearly delineated, that is, they differ from each other by constellation of 22 parameters of metabolism. This distinction is documented by calculating the squared Mahalanobis distances between them (Table 5).

Table 5 .

Squared Mahalanobis Distances between groups (over diagonal), F-values and p-levels (under diagonal)

\begin{tabular}{|l|c|c|c|}
\hline \multicolumn{1}{|c|}{ Groups } & $\begin{array}{c}\text { I } \\
\mathbf{( 2 4 )}\end{array}$ & II (12) & $\begin{array}{c}\text { III } \\
\mathbf{( 1 4 )}\end{array}$ \\
\hline Cluster I & $\mathbf{0 , 0}$ & 20,8 & 13,9 \\
\hline Cluster II & $\mathbf{4 , 1 9}$ & $\mathbf{0 , 0}$ & 12,9 \\
& $\mathbf{1 0}^{-3}$ & & \\
\hline Cluster III & $\mathbf{3 , 0 8}$ & $\mathbf{2 , 1 0}$ & $\mathbf{0 , 0}$ \\
& $\mathbf{0 0 3}$ & $\mathbf{0 3 6}$ & \\
\hline
\end{tabular}

Now let's return to a more detailed analysis of the Figure. The extreme right localization along the axis of the first root rats of first cluster reflects (Table 6) the maximum levels of parameters that correlate with this root directly. Among them, the levels of glomerulary filtration, diurese, phosphates excretion, calcium urine and malonic dialdehyde plasma are higher than normal, and normal levels of body mass, potassium urine and magnesium plasma are maximum among stressed animals.

On the other hand, members of this cluster are characterized by lower than normal activity of superoxide dismutase and normal but minimal for sampling levels of canalicular reabsorbtion, uric acid plasma and sodium erythrocytes, which correlate with the root inversely.

The members of the second cluster located on the opposite pole of the axis are characterized by decreased/increased or minimum/maximum levels of the listed parameters of metabolism. The projections on the axis of the members of the third cluster are mixed with those of the second cluster.

The delimitation of clusters occurs along the axis of the second root. The lowest localization of the rats of the third cluster reflects the highest levels of parameters that correlate with the root inversely, and the minimum levels of parameters directly related to the root. 
Table 6 .

Factor Structure Matrix (Correlations Variables-Canonical Roots) and Means of Roots and Variables

\begin{tabular}{|c|c|c|c|c|c|c|}
\hline $\begin{array}{l}\text { Variables currently } \\
\text { in the model }\end{array}$ & $\begin{array}{r}\text { Corr } \\
\text { Variable } \\
\mathbf{R}\end{array}$ & $\begin{array}{l}\text { tions } \\
\text { anonical } \\
\text { s }\end{array}$ & $\begin{array}{c}\text { Cluster } \\
\text { II } \\
(12)\end{array}$ & $\begin{array}{c}\text { Cluster } \\
\text { III } \\
(14)\end{array}$ & $\begin{array}{c}\text { Cluster } \\
\text { I } \\
(24)\end{array}$ & $\begin{array}{c}\text { Intact } \\
\text { rats } \\
(10)\end{array}$ \\
\hline Root $1(70,4 \%)$ & Root 1 & Root 2 & $-2,52$ & $-1,11$ & $+1,91$ & \\
\hline Body Mass & 0,163 & $-0,079$ & 251 & 261 & 268 & 263 \\
\hline Phosphates Excretion & 0,153 & 0,039 & 9,2 & 9,7 & 12,4 & 9,4 \\
\hline Malonic Dialdehyde Plasma & 0,147 & 0,080 & 67 & 68 & 84 & 63 \\
\hline Diurese & 0,137 & $-0,022$ & 1,44 & 1,63 & 1,90 & 1,44 \\
\hline Glomerulary Filtration & $\mathbf{0 , 0 7 1}$ & 0,029 & 114 & 115 & 140 & 86 \\
\hline Potassium Urine & 0,061 & 0,028 & 115 & 117 & 126 & 131 \\
\hline Magnesium Plasma & 0,050 & $-0,079$ & 0,71 & 0,86 & 0,87 & 0,88 \\
\hline Calcium Urine & 0,006 & $-0,008$ & 2,21 & 2,24 & 2,24 & 2,10 \\
\hline Sodium Erythrocytes & $-0,052$ & 0,064 & 23,8 & 22,4 & 22,3 & 22,0 \\
\hline Superoxide Dismutase Erythr & $-0,051$ & 0,045 & 56,9 & 54,7 & 54,1 & 58,0 \\
\hline Uric Acid Plasma & $-0,036$ & 0,057 & 790 & 690 & 688 & 662 \\
\hline Canalicular Reabsorbtion & $-0,021$ & $-0,010$ & 98,84 & 98,79 & 98,73 & 98,69 \\
\hline Root $2(29,6 \%)$ & Root 1 & Root 2 & $+1,46$ & $-1,84$ & $+0,34$ & \\
\hline Phosphate Plasma & 0,016 & $-0,275$ & 0,75 & 1,22 & 0,94 & 1,04 \\
\hline Amylase Plasma & $-0,002$ & $-0,241$ & 144 & 170 & 152 & 152 \\
\hline Creatinine Plasma & $-0,025$ & $-0,173$ & 76 & 95 & 79 & 73 \\
\hline Urea Plasma & $-0,074$ & $-0,172$ & 8,56 & 10,05 & 8,13 & 7,42 \\
\hline Uric Acid Excretion & 0,133 & 0,138 & 5,14 & 4,45 & 6,26 & 5,72 \\
\hline Middle Mass Molecules Urine & 0,057 & 0,133 & 169 & 151 & 166 & 182 \\
\hline Diene conjugates Urine & 0,121 & 0,131 & 1,71 & 1,60 & 1,87 & 1,86 \\
\hline Uric Acid Urine & 0,034 & 0,114 & 3,66 & 3,03 & 3,70 & 3,68 \\
\hline Katalase Urine & 0,015 & 0,078 & 150 & 139 & 146 & 123 \\
\hline Diene conjugates Plasma & 0,046 & 0,067 & 1,44 & 1,37 & 1,49 & 1,35 \\
\hline Lythogenicity Urine & curr $n$ & in mod & 0,84 & 0,74 & 0,93 & 0,90 \\
\hline
\end{tabular}

The application of the classifying functions (Table 7) enables the retrospective identification members of third cluster unmistakable, and the latter with two errors. Overall classification accuracy is $92 \%$ (Table 8).

Coefficients and Constants for Classification Functions

\begin{tabular}{|l|c|c|c|}
\hline \multicolumn{1}{|c|}{ Variables currently in the model } & I (0,48) & II (0,24) & III (0,28) \\
\hline Phosphate Plasma & $-456,8$ & $-459,8$ & $-456,4$ \\
\hline Body Mass & 22,98 & 22,69 & 22,97 \\
\hline Uric Acid Excretion & 130,7 & 129,9 & 128,8 \\
\hline Diene conjugates Urine & $-181,0$ & $-181,7$ & $-185,8$ \\
\hline Uric Acid Plasma & $-0,525$ & $-0,5147$ & $-0,519$ \\
\hline Urea Plasma & $-442,7$ & $-439,5$ & $-439,3$ \\
\hline Malonic Dialdehyde Plasma & 10,53 & 10,32 & 10,37 \\
\hline Glomerulary Filtration & $-3,518$ & $-3,562$ & $-3,503$ \\
\hline Middle Mass Molecules Urine & $-6,644$ & $-6,539$ & $-6,653$ \\
\hline Sodium Erythrocytes & 62,62 & 62,04 & 62,77 \\
\hline Phosphates Excretion & 317,8 & 314,8 & 315,4 \\
\hline Uric Acid Urine & $-54,31$ & $-56,33$ & $-53,48$ \\
\hline Creatinine Plasma & 73,91 & 73,44 & 73,67 \\
\hline
\end{tabular}




\begin{tabular}{|l|c|c|c|}
\hline \multicolumn{1}{|c|}{ Variables currently in the model } & I (0,48) & II (0,24) & III (0,28) \\
\hline Canalicular Reabsorbtion & 2881 & 2870 & 2876 \\
\hline Katalase Urine & $-5,299$ & $-5,166$ & $-5,197$ \\
\hline Diene conjugates Plasma & 220,8 & 222,8 & 224,3 \\
\hline Magnesium Plasma & 153,9 & 154,6 & 159,0 \\
\hline Amylase Plasma & $-1,981$ & $-1,973$ & $-1,929$ \\
\hline Diurese & -1331 & -1323 & -1321 \\
\hline Calcium Urine & 224,4 & 219,4 & 221,7 \\
\hline Potassium Urine & $-0,251$ & $-0,329$ & $-0,305$ \\
\hline Superoxide Dismutase Erythrocytes & $-18,29$ & $-18,06$ & $-18,22$ \\
\hline Constants & -146617 & -145473 & -146189 \\
\hline
\end{tabular}

Table 8.

Classification Matrix

Rows: Observed classifications; Columns: Predicted classifications

\begin{tabular}{|c|c|c|c|c|}
\hline Cluster & Percent & I & II & III \\
\cline { 3 - 5 } & correct & $\mathbf{p = 0 , 4 8}$ & $\mathbf{p = 0 , 2 4}$ & $\mathbf{p = 0 , 2 8}$ \\
\hline I & 91,7 & $\mathbf{2 2}$ & 0 & 2 \\
\hline II & 83,3 & 1 & $\mathbf{1 0}$ & 1 \\
\hline III & 100 & 0 & 0 & $\mathbf{1 4}$ \\
\hline Total & 92,0 & 23 & 10 & 17 \\
\hline
\end{tabular}

The obtained experimental data complement and refine our previous observations of humans. It was found that the susceptibility or resistance of the immune status to the stress sympathicotonic shift of autonomic regulation is conditioned by the combination of EEG, HRV, endocrine and metabolic parameters. Discriminant analysis revealed that testosterone is the main factor that conditioning the sensitivity of immune status to chronic stress. Sensitizing (immunosuppressive) factors are also Ca/K-ratio of plasma and total cholesterol, instead LDLP cholesterol, creatinineuria, P/Ca-ratio of urine as marker of parathyroid activity, spectral power of VLF band HRV as well as entropy of HRV are desensitizing (immunoprotective) factors [16].

In another observation, we found that the immune response to the antipode of stressors adaptogens is also individual in nature and is clearly conditioned by the constellation of initial parameters of the neuroendocrine-immune complex and metabolism [17-21].

\section{CONFORMITY TO ETHICAL STANDARDS}

Experiments on animals have been carried out in accordance with the provisions of the Helsinki Declaration of 1975, revised and supplemented in 2002 by the Directives of the National Committees for Ethics in Scientific Research.

The conduct of experiments was approved by the Ethics Committee of the Danylo Halytskyi L'viv National Medical University. The modern rules for the maintenance and use of laboratory animals complying with the principles of the European Convention for the Protection of Vertebrate Animals used for scientific experiments and needs are observed (Strasbourg, 1985).

Рекомендовано до друку колісією з біоетики

\section{REFERENCES}

1. Zajats LM, Polovynko IS, Zukow W, Yanchij RI, Mysakovets' OG, Mel'nyk OI, Hrytsak YaL. Neuroendocrine-immune relatioships in rats females. Journal of Education, Health and Sport. 2017;7(10):59-78.

2. Polovynko IS. Integrated quantitative estimation of neuro-endocrine manifestations of chronic stress in female rats. Experimental and Clinical Physiology and Biochemistry. 2017;3(79):5-10. 
3. Popovych IL, Gozhenko AI, Zukow W, Polovynko IS. Variety of Immune Responses to Chronic Stress and their Neuro-Endocrine Accompaniment. Scholars' Press. Riga; 2020. 172 p.

4. Popovych IL, Polovynko IS, Zajats LM, Mel'nyk OI. Sexual dimorphism of the neuroendocrine-immune complex and its reactions on chronic stress at rats. Experimental and Clinical Physiology and Biochemistry. 2018;3(83):5-17.

5. Zavidnyuk YV, Mel'nyk OI, Mysakovets' OG. Factor analysis of the information field of the neuroendocrine-immune complex and metabolism in female rats. Experimental and Clinical Physiology and Biochemistry. 2019;3(87):12-22.

6. Gozhenko AI. Functional-metabolic continuum [in Russian]. J of NAMS of Ukraine. $2016 ; 22$ (1): 3-8.

7. Reznikov AG, Pishak VP, Nosenko ND, Tkachuk SS, Myslyts'kyi VF. Prenatal Stress and Neuroendocrine Pathology [in Russian]. Chernivtsi. Medakademiya; 2004. 351 p.

8. Goryachkovskiy AM. Clinical Biochemistry [in Russian]. Odesa. Astroprint; 1998. 608 p.

9. Gavrilov VB, Mishkorudnaya MI. Spectrophotometric determination of plasma levels of lipid hydroperoxides [in Russian]. Laboratornoye Delo. 1983;3:33-6.

10. Andreyeva LI, Kozhemyakin LA, Kishkun AA. Modification of the method for determining the lipid peroxide in the test with thiobarbituric acid [in Russian]. Laboratornoye Delo. 1988;11:41-3.

11. Dubinina $Y Y$, Yefimova $L F$, Sofronova $L N$, Geronimus $A L$. Comparative analysis of the activity of superoxide dismutase and catalase of erythrocytes and whole blood from newborn children with chronic hypoxia [in Russian]. Laboratornoye Delo. 1988;8:16-9.

12. Makarenko YeV. A comprehensive definition of the activity of superoxide dismutase and glutathione reductase in red blood cells in patients with chronic liver disease [in Russian]. Laboratornoye Delo. 1988;11:48-50.

13. Korolyuk MA, Ivanova MI, Mayorova IG, Tokarev VYe. The method for determining the activity of catalase [in Russian]. Laboratornoye Delo. 1988;1:16-9.

14. Flyunt VR, Flyunt ISS, Fil'VM, Kovbasnyuk MM, Hryvnak RF, Popel SL, Zukow W. Relationships between caused by drinking of bioactive water Naftussya changes in urine lithogenicity and neuro-humoral-immune factors in humans with theirs abnormalities. Journal of Education, Health and Sport. 2017;7(3):11-30.

15. Klecka WR. Discriminant Analysis [trans. from English in Russian] (Seventh Printing, 1986). In: Factor, Discriminant and Cluster Analysis. Moskwa. Finansy i Statistika; 1989: 78-138.

16. Lukyanchenko OI, Mel'nyk OI, Gozhenko OA, Zukow W, Popovych IL. Features of the HRV, endocrine and metabolic parameters in persons whose immune status is susceptible or resistant to chronic stress. Journal of Education, Health and Sport. 2020;10(3):177-87.

17. Mel'nyk OI, Struk ZD, Zukow W, Popovych IL. Vegetative, endocrine and metabolic accompaniments of individual immune responses to adaptogenic balneotherapy. Journal of Education, Health and Sport. 2019;9(12):207-29.

18. Mel'nyk OI, Struk ZD. Predictors of individual immune responses to adaptogens. Experimental and Clinical Physiology and Biochemistry. 2019;88(4):5-15.

19. Struk ZD, Mel'nyk OI, Zukow W, Popovych IL. Vegetative and endocrine predictors of individual immune responses to adaptogenic balneotherapy. Journal of Education, Health and Sport. 2020;10(1):218-25.

20. Struk ZD, Mel'nyk OI, Zukow W, Popovych IL. Metabolic predictors of individual immune responses to adaptogenic balneotherapy. Journal of Education, Health and Sport. 2020;10(2):223-30.

21. Mel'nyk OI, Struk ZD. The variety of immune responses to adaptogenic balneotherapy is strictly deterministic. Experimental and Clinical Physiology and Biochemistry. 2020;89(1):5-14. 